\title{
Strategi Pemecahan Masalah Geometri Mahasiswa Calon Guru Matematika: Antara Prediksi dan Kenyataan
}

\author{
Al Jupri ${ }^{1 *}$, Elah Nurlaelah ${ }^{2}$, Jarnawi Afgani Dahlan $^{3}$ \\ 1,2,3 Universitas Pendidikan Indonesia, Bandung, Jawa Barat 40154, Indonesia \\ Pengiriman: 10/Juli/2021; Diterima: 24/September/2021; Publikasi: 30/September/2021 \\ DOI: https://doi.org/10.31629/jg.v6i2.3539
}

\begin{abstract}
Abstrak
Kemampuan pemecahan masalah, termasuk dalam topik geometri, merupakan kemampuan yang perlu dimiliki para mahasiswa calon guru matematika sebagai bekal karir mereka di masa depan. Tujuan dari penelitian ini adalah untuk menginvestigasi kemampuan pemecahan masalah mahasiswa calon guru matematika dalam menyelesaikan soal-soal geometri. Untuk mencapai tujuan ini, penelitian ini menggunakan metode kualitatif, desain studi kasus, dalam bentuk tes tertulis individu melibatkan 31 mahasiswa calon guru matematika di salah satu universitas negeri di kota Bandung, Indonesia. Dalam studi ini strategi pemecahan masalah hasil prediksi yang dibuat peneliti dibandingkan dengan strategi pemecahan masalah yang digunakan mahasiswa. Hasil penelitian menunjukkan bahwa meskipun sebagian strategi pemecahan masalah yang digunakan mahasiswa sesuai prediksi, di mana proses dan hasil pemecahan masalah yang mereka lakukan sudah benar, namun sebagian besar mahasiswa masih kurang komprehensif dalam memberikan argumentasi terhadap langkah penyelesaian masalah yang mereka gunakan. Selain itu, beberapa kesulitan yang mahasiswa hadapi dalam proses pemecahan masalah diidentifikasi dan didiskusikan. Dapat disimpulkan bahwa terdapat kesenjangan antara strategi pemecahan masalah yang diprediksi dan strategi pemecahan masalah yang digunakan mahasiswa dalam proses pemecahan masalah.
\end{abstract}

Kata kunci: geometri; pemecahan masalah; strategi pemecahan masalah; calon guru matematika

\begin{abstract}
Problem solving, including within the topics of geometry, concerns an ability that should be acquired by prospective mathematics teachers as a provision for their future careers. This research aims to investigate problem solving ability of prospective mathematics teachers in solving geometry problems. To reach this aim, this research used a qualitative case study method, through administering an individual written test involving 31 prospective mathematics teachers in one of the state universities in Bandung, Indonesia. In this study, predicted problem solving strategies were compared to actual problem solving strategies used by prospective mathematics teachers. The results showed that even if some of the prospective teachers' problem solving strategies are in line with our predictions, in which processes and solutions are correct, still most of the other students are not fully comprehensive in terms of lack of clear explanation on their problem solving processes. In addition, students' difficulties during problem solving processes are identified and discussed. It can be concluded that there is a discrepancy between problem solving strategies and actual problem solving strategies used by the prospective mathematics teachers.
\end{abstract}

Keywords: geometry; problem solving; problem solving strategies; prospective mathematics teachers

*Penulis Korespondensi

Email Address: aljupri@upi.edu

Handphone : : +6281223900483 


\section{JURNAL GANTANG. September 2021; VI(2): 141 - 149 \\ p-ISSN. 2503-0671 \\ e-ISSN. 2548-5547}

\section{Pendahuluan}

Pemecahan masalah merupakan salah satu kecakapan yang perlu dikuasai untuk hidup di abad 21 (Kemdikbud, 2017). Kecakapan pemecahan masalah, khususnya dalam menangani permasalahan non-rutin, perlu dikuasai oleh para siswa dari jenjang pendidikan dasar hingga menengah sebagai bekal hidup mereka di masa depan, baik dalam dunia akademik, dunia kerja, maupun kehidupan bermasyarakat sebagai warga Negara (De Lange, 2006; Jupri \& Rosjanuardi, 2020; Kemdikbud, 2013; Widana, 2017). Kecakapan pemecahan masalah siswa di jenjang sekolah dapat ditumbuhkembangkan oleh para guru, salah satunya, melalui belajar matematika baik pada topik aritmetika, aljabar, statistika, peluang, ataupun geometri (Budhi \& Kartasasmita, 2015; Jupri, Gozali, et al., 2020; Jupri \& Syaodih, 2016). Geometri merupakan bagian dari matematika yang menyediakan kesempatan belajar bagi siswa dalam mengasah dan menumbuhkembangkan kreativitas dan pemecahan masalah (Levav-Waynberg \& Leikin, 2012). Hal ini menunjukkan bahwa kecakapan pemecahan masalah perlu dikuasai para guru agar dapat membimbing para siswanya dalam pembelajaran matematika. Kemampuan pemecahan masalah para guru matematika Indonesia di masa depan, baik secara langsung ataupun tidak, bergantung kepada kemampuan pemecahan masalah calon guru matematika saat ini. Oleh karena itu, kemampuan pemecahan masalah mahasiswa calon guru matematika, khususnya dalam geometri, perlu dikaji secara lebih serius.

Hasil-hasil penelitian terdahulu menunjukkan bahwa kemampuan melakukan pembuktian dan pemecahan masalah para mahasiswa calon guru matematika di Indonesia dalam geometri tampaknya masih perlu ditingkatkan (Jupri, 2017; Jupri, Fatimah, et al., 2020). Yuwono (2016) menemukan bahwa sebagian mahasiswa calon guru matematika masih kesulitan dalam menyelesaikan permasalahan mengenai penggunaan konsep kesebangunan segitiga dan proses pembuktian luas daerah segitiga dan segiempat. Samo (2017) menemukan bahwa kemampuan pemecahan masalah mahasiswa calon guru dalam geometri dengan konteks budaya relatif beragam dan cenderung rendah untuk sebagian besar mahasiswa. Pada penelitian lain diperoleh temuan bahwa mahasiswa calon guru matematika berkemampuan kurang kesulitan dalam proses pembuktian dan pemecahan masalah geometri (Masfingatin et al., 2018).

Hasil-hasil penelitian di Indonesia yang diuraikan tersebut menunjukkan bahwa kemampuan melakukan pembuktian dan pemecahan masalah dalam geometri merupakan dua hal yang tidak bisa dipisahkan dan bahkan dapat dipandang sama. Dengan perkataan lain, sebagaimana penelitian-penelitian lain di luar Indonesia, pembuktian dalam matematika dapat dipandang sebagai suatu persoalan pemecahan masalah (Koichu \& Leron, 2015; Weber, 2005).

Secara umum, pemecahan masalah dapat dimaknai sebagai suatu proses penerapan pengetahuan yang sudah didapatkan sebelumnya kepada situasi yang baru dan belum dikenal (Posamentier \& Stepelman, 1990). Oleh karena itu, pemecahan masalah dalam geometri berarti penerapan pengetahuan geometri yang sudah diperoleh dari proses belajar sebelumnya untuk memecahkan soal atau permasalahan geometri yang baru bagi seorang pemecah masalah. Menurut Polya (1973), secara umum, terdapat empat langkah strategi (heuristik) pemecahan masalah, yaitu understanding the problem (memahami masalah); devising a plan (merencanakan pemecahan masalah); carrying out the plan (mengerjakan rencana yang sudah disusun); dan looking back (memeriksa kembali proses dan hasil pemecahan masalah yang sudah dilakukan). Yang dilakukan pada langkah memahami masalah, di antaranya, adalah menentukan hal yang ditanyakan, dan menentukan semua informasi serta kondisi yang diketahui dalam soal atau masalah. Yang dilakukan pada langkah merencanakan penyelesaian masalah adalah menghubungkan antara yang ditanyakan dan hal-hal yang 
diketahui, membuat tabel atau diagram atau gambar yang relevan sesuai kondisi dan informasi yang diberikan dalam permasalahan, dan membuat model matematik untuk diselesaikan. Yang dilakukan pada langkah penyelesaian masalah adalah menyelesaikan permasalahan yang dihadapi sesuai rencana yang disusun, dan bila mengalami kegagalan, maka perlu kembali lagi membuat atau memperbaiki perencanaan penyelesaian masalah. Akhirnya, yang dilakukan pada langkah melihat kembali adalah memeriksa proses dan hasil penyelesaian masalah — apakah masuk akal atau tidak, serta bila memungkinkan menyelesaikan masalah yang sudah diselesaikan dengan cara berbeda. Keempat langkah heuristik pemecahan masalah ini, pada hakikatnya, serupa dengan proses pembuktian dalam matematika dan khususnya pada pembuktian dalam geometri (Koichu \& Leron, 2015; Polya, 1973; Weber, 2005). Oleh karena itu, pemecahan masalah dalam penelitian ini meliputi pemecahan masalah matematika biasa dan pemecahan masalah mengenai pembuktian matematika, khususnya pada topik geometri.

Berdasarkan uraian di atas, maka dipandang perlu untuk melakukan investigasi permulaan mengenai kemampuan pemecahan masalah para mahasiswa calon guru matematika, khususnya dalam topik geometri. Dengan diketahuinya kemampuan ini, maka dapat diperoleh manfaat berupa informasi mengenai perbaikan mutu pengembangan bahan ajar dan mutu proses perkuliahan untuk mahasiswa calon guru matematika di masa mendatang. Dengan demikian, tujuan dari penelitian ini adalah untuk menginvestigasi kemampuan pemecahan masalah mahasiswa calon guru matematika dalam topik geometri.

\section{Metode Penelitian}

Untuk menginvestigasi kemampuan pemecahan masalah geometri mahasiswa calon guru matematika, maka penelitian ini menggunakan metode kualitatif dengan desain studi kasus (Sukmadinata, 2012) melalui empat tahapan berikut. Pertama, dua soal geometri mengenai pemecahan masalah biasa dan pemecahan masalah pembuktian dipilih dan diadaptasi. Dua soal tersebut berasal dari bukubuku geometri yang relevan (Jupri, 2019; Posamentier \& Stepelman, 1990). Gambar 1 menyajikan soal pemecahan masalah geometri biasa, yang secara umum - meski tidak terbatas kepada-menuntut penggunaan konsep luas daerah, sifat-sifat segitiga, dan lingkaran. Gambar 2 menyajikan soal pemecahan masalah geometri tipe pembuktian, yang menuntut penggunaan konsep sifat-sifat segitiga dan sifat-sifat geometri lainnya, yang dapat dipandang juga sebagai suatu soal pemecahan masalah.

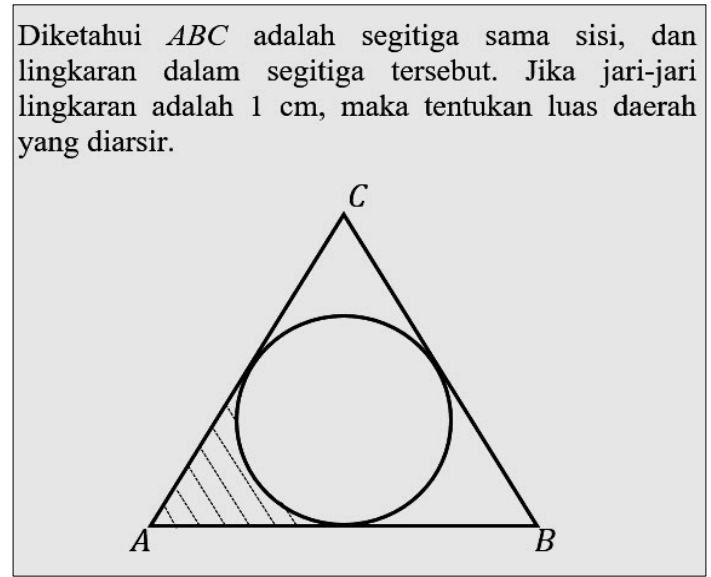

Gambar 1. Soal pemecahan masalah geometri

Diketahui segitiga $A B C$ sama sisi dengan $C D$ adalah garis tinggi segitiga tersebut. Misalkan $P$ adalah sembarang titik di dalam daerah segitiga $A B C$. Dari $P$ ditarik garisgaris tegak lurus sisi-sisi $A B, B C$, dan $A C$ sehingga memotong ketiga sisi tersebut berturut-turut di $Q, R$, dan $S$ (lihat gambar). Buktikan bahwa $C D=P Q+P R+P S$.

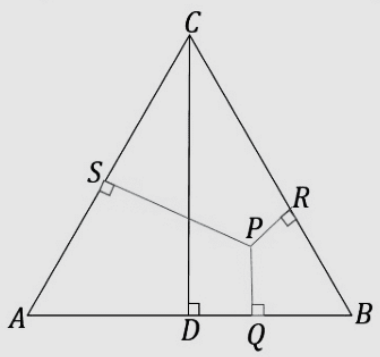

Gambar 2. Soal pembuktian dalam geometri

Kedua, prediksi strategi pemecahan masalah terhadap soal-soal yang telah dipilih dan diadaptasi pada tahap sebelumnya pun dibuat. Pada tahap ini, berbagai strategi pemecahan 


\section{JURNAL GANTANG. September 2021; VI(2): 141 - 149 \\ p-ISSN. 2503-0671 \\ e-ISSN. 2548-5547}

masalah terhadap masing-masing soal yang dipilih dituliskan secara lengkap dan komprehensif. Prediksi strategi pemecahan masalah dilakukan berdasarkan pengalaman para peneliti sebagai pengajar di perguruan tinggi pendidikan guru serta merujuk pula kepada hasilhasil penelitian dan literatur yang relevan.

Ketiga, tes permulaan kemampuan pemecahan masalah geometri diberikan kepada 31 mahasiswa semester empat program studi pendidikan matematika, sebagai calon guru matematika, di salah satu perguruan tinggi negeri di kota Bandung. Tes tertulis dilakukan secara individu selama 60 menit, di mana mahasiswa diminta menyelesaikan dua soal yang telah disiapkan sebelumnya, di luar waktu perkuliahan geometri.

Keempat, data yang telah terkumpul kemudian dianalisis dengan menggunakan heuristik atau strategi pemecahan masalah menurut Polya (1973). Strategi pemecahan masalah yang digunakan mahasiswa kemudian dibandingkan dengan prediksi strategi pemecahan masalah yang sudah dibuat peneliti. Selain itu, analisis data yang dilakukan mencakup pula telaah kesulitan yang dialami mahasiswa dalam menyelesaikan permasalahan geometri yang diberikan.

\section{Hasil dan Pembahasan}

Pada bagian ini diuraikan hasil dan pembahasan mengenai kemampuan mahasiswa calon guru matematika yang diuji dengan dua soal geometri tipe pemecahan masalah. Uraian hasil dan pembahasan untuk setiap soal meliputi temuan banyaknya mahasiswa yang berhasil menyelesaikan soal; perbandingan antara strategi pemecahan masalah hasil prediksi dan strategi pemecahan masalah yang dilakukan mahasiswa; dan kumpulan aneka kesulitan yang dialami mahasiswa dalam proses pemecahan masalah.

\section{Hasil dan Pembahasan Soal Pemecahan Masalah Geometri Biasa}

Soal pemecahan masalah geometri biasa adalah soal geometri yang terdapat pada Gambar 1. Salah satu prediksi strategi penyelesaian masalah yang dibuat tim peneliti terhadap soal ini disajikan pada Gambar 3. Hal kunci yang perlu ditemukan agar permasalahan pada Gambar 1 dapat diselesaikan adalah bahwa kita perlu mengetahui panjang sisi segitiga sama sisi $A B C$. Langkah penting yang dapat dilakukan untuk mencapai hal ini adalah dengan mencerminkan segitiga $A O T$ terhadap garis $A T$ sehingga terbentuk segitiga sama sisi AOR. Selanjutnya proses penyelesaian dituliskan secara ringkas pada Gambar 3.

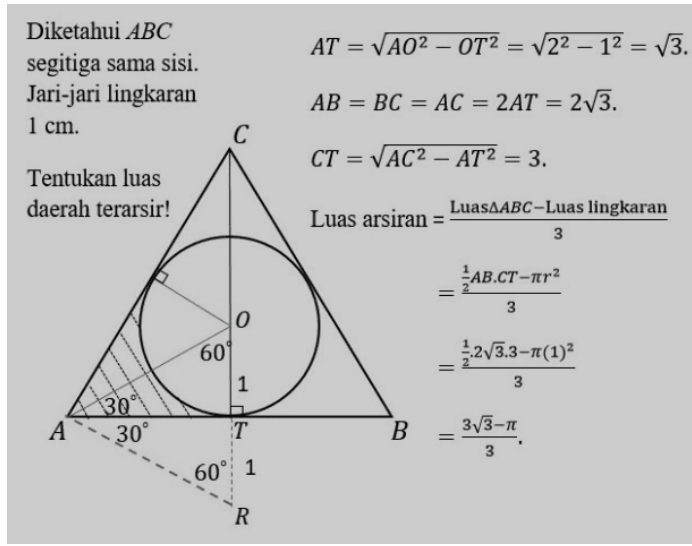

Gambar 3. Prediksi penyelesaian soal pemecahan masalah geometri biasa

Prediksi strategi pemecahan masalah lain yang telah disusun adalah sebagai berikut. Untuk menentukan panjang sisi segitiga sama sisi $A B C$, maka dapat menggunakan sifat-sifat perbandingan trigonometri pada segitiga AOT. Misalkan dengan menggunakan perbandingan trigonometri tangen sudut $A$ pada segitiga $A O T$, akan diperoleh panjang $A T$, yang berakibat panjang $A B$ dapat ditentukan. Untuk selanjutnya proses penyelesaiannya serupa dengan yang tertuang pada Gambar 3. Strategi-strategi lainsaat kami membuat prediksi ini-diyakini masih banyak lagi sebab soal ini bersifat terbuka dalam hal dapat diselesaikan dengan cara-cara lain yang berbeda.

Terkait hasil tes tertulis terhadap mahasiswa calon guru matematika, diperoleh temuan sebagai berikut. Dari 31 mahasiswa calon guru matematika yang mengerjakan soal pemecahan masalah geometri biasa ini (Gambar 1) ditemukan bahwa 10 mahasiswa dapat menyelesaikan soal dengan benar dan 21 
mahasiswa yang lain tidak berhasil menyelesaikannya. Dari 21 mahasiswa yang tidak berhasil menjawab benar, diketahui bahwa 10 mahasiswa memiliki ide yang mengarah benar tetapi tidak sampai kepada penyelesaian akhir dan 11 mahasiswa memberikan penyelesaian dan jawaban yang keliru.

Gambar 4 menyajikan satu contoh jawaban mahasiswa calon guru matematika yang benar. Jawaban pada Gambar 4 ini disajikan oleh delapan mahasiswa dengan gagasan penyelesaian serupa dengan prediksi jawaban yang telah dibuat oleh tim peneliti (lihat Gambar 3). Namun demikian, ada informasi atau keterangan yang kurang lengkap dalam proses penyelesaiannya. Misalkan, pada jawaban tersebut mahasiswa tidak memberi keterangan asal-muasal diperolehnya panjang $A O$ dan panjang $A D$. Hal ini, dapat diduga bahwa mahasiswa telah menggunakan sifat-sifat perbandingan trigonometri (seperti yang diprediksikan), ataupun telah menggunakan sifatsifat segitiga siku-siku yang sudut-sudutnya 3060-90 (dalam derajat). Ditinjau dari perspektif heuristik pemecahan masalah Polya (1973), maka dapat dikatakan bahwa mahasiswa tidak secara komprehensif menuliskan proses perencanaan penyelesaian masalah.

Sebanyak dua dari delapan penyelesaian masalah dengan jawaban benar lainnya menggunakan strategi berbeda-beda. Satu mahasiswa menggunakan aturan Cosinus untuk menentukan jarak antara dua titik singgung lingkaran dalam segitiga, di mana jarak ini sama dengan panjang $A D=1 / 2 A B$. Selanjutnya mahasiswa menggunakan cara serupa seperti pada Gambar 4

Satu mahasiswa lagi menggunakan sifat titik berat dan garis berat dari segitiga sama sisi $A B C$ untuk menentukan panjang garis berat yang panjangnya sama dengan garis tinggi segitiga $A B C$. Dengan mengetahui tinggi segitiga sama sisi $A B C$ ini, maka panjang sisi segitiga $A B C$ pun dapat diketahui. Akibatnya luas daerah segitiga sama sisi $A B C$ dapat dengan mudah diperoleh dan luas daerah yang diarsirpun akan didapatkan.

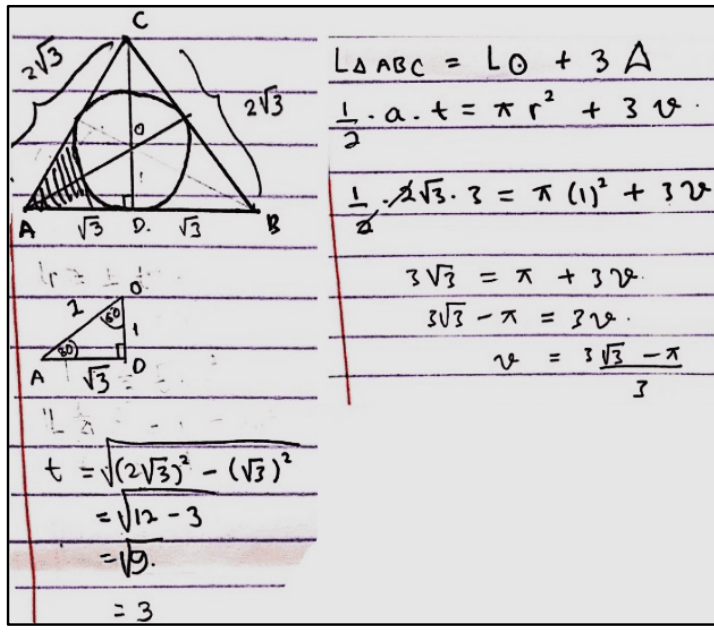

Gambar 4. Hasil pekerjaan mahasiswa dalam pemecahan masalah geometri biasa

Dari temuan-temuan di atas, maka dapat dikatakan bahwa strategi-strategi pemecahan masalah yang disajikan mahasiswa calon guru matematika sebagian sudah sesuai prediksi yang dibuat tim peneliti, meski di beberapa bagian jawaban mahasiswa masih perlu keterangan tambahan. Sejalan dengan hasil-hasil penelitian terdahulu (Jupri, Fatimah, et al., 2020; LevavWaynberg \& Leikin, 2012) temuan tentang beraneka ragam strategi penyelesaian masalah mahasiswa menunjukkan bahwa soal yang disajikan menuntut dan mengasah kreativitas berpikir mahasiswa calon guru matematika.

Selain temuan aneka ragam strategi penyelesaian masalah, beberapa kesulitan mahasiswa pun telah kami identifikasi dari jawaban-jawaban yang keliru. Kesulitankesulitan tersebut, di antaranya, meliputi kesulitan menggali dan menghubungkan sifatsifat segitiga sama sisi dan lingkaran dalam segitiga untuk menentukan panjang sisi segitiga; kesulitan dalam menerapkan sifat ketegaklurusan garis singgung lingkaran terhadap jari-jari lingkaran pada titik singgung; kekurangtahuan sifat garis bagi segitiga; dan ketidakmampuan membuat garis bantu untuk menemukan sifat-sifat penting dari suatu segitiga (Palatnik \& Dreyfus, 2019). Dalam perspektif Polya (1973), kesulitankesulitan ini menunjukkan ketidakmampuan mahasiswa dalam membuat perencanaan pemecahan masalah dengan baik. 


\section{JURNAL GANTANG. September 2021; VI(2): 141 - 149 \\ p-ISSN. 2503-0671 \\ e-ISSN. 2548-5547}

Ketidakmampuan itu terutama dalam hal menghubungkan sifat-sifat geometris yang ada dan dapat digali dari soal dengan hal yang ditanyakan dalam soal.

\section{Hasil dan Pembahasan Soal Pemecahan Masalah Pembuktian Geometri}

Soal pemecahan masalah pembuktian geometri dalam penelitian ini adalah soal yang disajikan pada Gambar 2. Tim peneliti telah menyiapkan tiga prediksi strategi berbeda dalam menyelesaikan soal pembuktian ini. Gambar 5 menyajikan salah satu prediksi strategi penyelesaian soal pembuktian yang telah disusun. Gagasan kunci dalam pembuktian permasalahan ini adalah pemanfaatan konsep luas daerah segitiga dan sifat-sifat segitiga sama sisi. Langkah esensial dalam pembuktian ini adalah pengkonstruksian garis-garis bantu $A P, B P$, dan $C P$. Selanjutnya proses pembuktian disajikan secara ringkas pada Gambar 5.

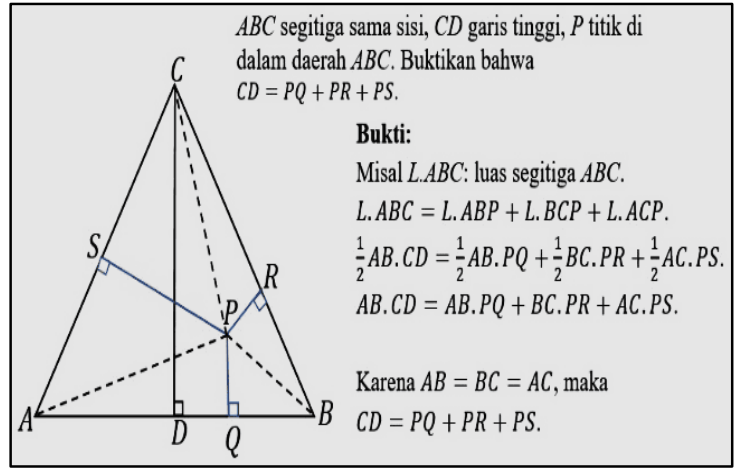

Gambar 5. Prediksi penyelesaian soal pembuktian geometri

Prediksi strategi-strategi pemecahan masalah yang lain disusun berdasarkan literatur (Jupri, 2019; Posamentier \& Stepelman, 1990) yakni menggunakan gagasan kesejajaran garis dan sifat segitiga sama sisi, serta berdasarkan temuan penelitian sebelumnya dengan menggunakan konsep geometri analitik (Jupri, 2020). Selain itu, dapat diduga bahwa strategi pembuktian lain bisa jadi banyak ragamnya. Termasuk, misalnya, pembuktian dengan menggunakan konsep vektor (Samelson, 2003) ataupun pembuktian tanpa kata-kata secara visual (Kawasaki, 2005).
Terkait hasil tes soal ini terhadap 31 mahasiswa calon guru matematika, diperoleh temuan berikut. Sebanyak 8 mahasiswa dapat menuliskan pembuktian dengan benar, sedangkan 23 mahasiswa tidak sampai kepada pembuktian yang benar. Dari 8 mahasiswa yang dapat melakukan pembuktian tersebut, diketahui bahwa secara umum strategi pembuktiannya serupa dengan yang telah diprediksi.

Gambar 6 menyajikan satu contoh pekerjaan mahasiswa dalam pemecahan masalah pembuktian geometri. Tampak bahwa proses pembuktiannya serupa dengan prediksi yang telah disusun.

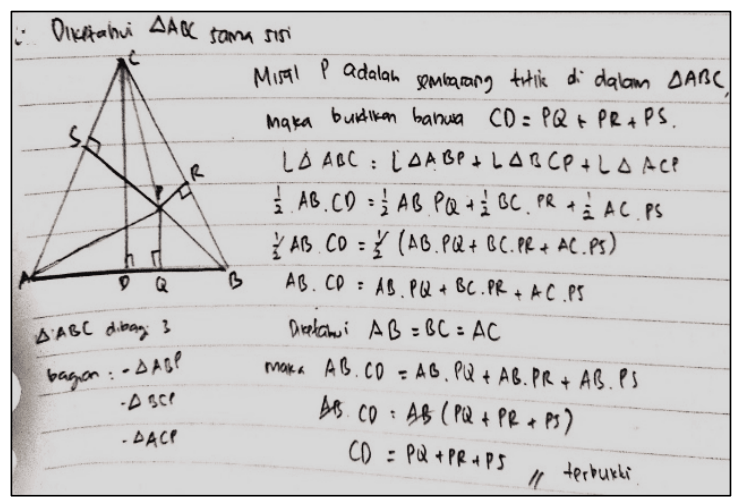

Gambar 6. Pekerjaan mahasiswa dalam pemecahan masalah pembuktian geometri

Strategi dengan gagasan sama seperti yang diprediksikan, tapi dengan prosedur sedikit berbeda, adalah ketika mahasiswa memandang segitiga sama sisi $A B C$ dalam soal tersusun atas enam segitiga siku-siku dengan titik $P$ sebagai titik persekutuan keenam segitiga tersebut. Keenam segitiga siku-siku tersebut adalah segitiga $A P Q, B P Q, B P R, C P R, C P S$, dan $A P S$ (lihat Gambar 6). Selanjutnya dengan menggunakan gagasan rumus luas daerah segitiga, maka dapat dibuktikan bahwa $C D=P Q$ $+P R+P S$.

Strategi pembuktian dengan menggunakan konsep kesejajaran garis dan sifatsifat segitiga sama sisi seperti yang ada dalam literatur (Jupri, 2019; Posamentier \& Stepelman, 1990) ataupun hasil penelitian sebelumnya (Jupri, 2020) tidak ditemukan pada hasil pekerjaan tertulis 31 mahasiswa calon guru yang diteliti. 
Mungkin, bila para mahasiswa tersebut diberi kesempatan yang lebih lama, temuan-temuan yang akan diperoleh barangkali akan lebih baik.

Dari uraian temuan perbandingan strategi-strategi pembuktian mahasiswa dan prediksi strategi yang disusun, dapat dikatakan bahwa aspek pembuktian serupa dengan aspek pemecahan masalah matematis secara umum seperti yang digagas Polya (1973). Dalam proses pembuktian, langkah menentukan hal yang perlu dibuktikan dan memahami informasi yang diberikan sama seperti langkah memahami masalah. Proses menghubung-hubungkan antara yang akan dibuktikan dan yang diketahui, serupa dengan langkah perencanaan pemecahan masalah. Eksekusi proses pembuktian serupa dengan pelaksanaan pemecahan masalah. Langkah memeriksa kembali baik dalam proses pemecahan masalah biasa ataupun proses pembuktian dapat dikatakan tidak berbeda. Tampaknya, atas dasar inilah, dapat dikatakan bahwa proses pembuktian geometri sama saja dengan proses pemecahan masalah geometri (Koichu \& Leron, 2015; Polya, 1973; Weber, 2005). Menurut Polya (1973) problem to prove (masalah untuk membuktikan) kira-kira serupa dengan problem to solve (masalah untuk menyelesaikan).

Kesulitan-kesulitan yang dapat diidentifikasi dari pekerjaan tertulis mahasiswa dalam menyelesaikan soal pembuktian geometri, di antaranya, meliputi kesulitan dalam mengkonstruksi garis-garis yang tepat sehingga terbentuk misalnya bahwa suatu segitiga tersusun atas beberapa segitiga lain; kesulitan memanfaatkan sifat-sifat segitiga sama sisi dalam proses pembuktian; dan kesulitan dalam menentukan konsep yang tepat untuk digunakan dalam proses pembuktian. Beberapa mahasiswa berusaha menggunakan teorema Pythagoras dalam mencari hubungan panjang segmen $C D$ dengan $P R, P Q$ dan $P S$; dan sebagian mahasiswa yang lain menggunakan konsep-konsep geometri lain yang tidak secara langsung mengarah kepada pembuktian yang benar. Dari temuan kesulitankesulitan ini dapat dikatakan bahwa proses pembuktian membutuhkan kemampuan berpikir kreatif dalam menghubung-hubungkan antar konsep agar mengarah kepada hal yang akan dibuktikan (Jupri, Fatimah, et al., 2020; LevavWaynberg \& Leikin, 2012). Dengan demikian, proses pembuktian dalam geometri serupa dengan proses pemecahan masalah geometri biasa.

\section{Kesimpulan}

Dari hasil dan pembahasan yang telah diuraikan sebelumnya, maka dapat ditarik beberapa kesimpulan berikut. Terkait temuan kemampuan pemecahan masalah, tampak bahwa hanya sepertiga jumlah mahasiswa calon guru matematika yang dapat melakukan proses pemecahan masalah geometri dengan baik dan sesuai harapan: baik untuk pemecahan masalah geometri biasa, maupun pemecahan masalah pembuktian geometri. Temuan ini merupakan indikasi perlunya perbaikan mutu pengajaran perkuliahan geometri bagi mahasiswa calon guru matematika di masa mendatang. Perbaikan mutu pengajaran geometri tersebut bisa dilakukan, misalnya, dalam bentuk perbaikan mutu bahan ajar untuk mahasiswa dan perbaikan proses perkuliahan yang memberi kesempatan lebih luas kepada mahasiswa dalam hal pemecahan masalah. Hal ini merupakan gagasan penting yang dapat diteliti di masa mendatang.

Perihal perbandingan strategi pemecahan masalah hasil prediksi dan yang dilakukan mahasiswa, dapat dikatakan bahwa meskipun sebagian strategi pemecahan masalah yang digunakan mahasiswa sudah sesuai prediksi, namun sebagian besar mahasiswa yang lain masih kurang komprehensif dalam memberikan argumentasi terhadap langkah penyelesaian masalah yang mereka gunakan. Dengan perkataan lain, terdapat kesenjangan antara strategi pemecahan masalah yang diprediksi dan strategi pemecahan masalah yang terjadi pada kenyataan. Untuk penelitian ke depan, tentunya perlu studi yang mendalam mengenai kemampuan pemecahan masalah mahasiswa calon guru matematika ini ditinjau dari berbagai aspek, seperti keluasan dan kedalaman materi geometri yang diujikan, validitas empiris soal-soal yang diujikan, maupun banyaknya sampel yang diteliti. 


\section{JURNAL GANTANG. September 2021; VI(2): 141 - 149 \\ p-ISSN. 2503-0671 \\ e-ISSN. 2548-5547}

Ihwal kesulitan mahasiswa calon guru matematika dalam proses pemecahan masalah dan pembuktian geometri, hal ini tampaknya perlu penelaahan lebih mendalam dengan menggunakan kerangka analisis yang relevan dalam menelaah kesulitan-kesulitan mahasiswa. Melalui cara ini, diharapkan bahwa mutu pendidikan calon guru matematika akan makin meningkat di masa mendatang.

\section{Ucapan Terima Kasih}

Penelitian ini didanai oleh Fakultas Pendidikan Matematika dan Ilmu Pengetahuan Alam (FPMIPA), Universitas Pendidikan Indonesia, melalui skema Penelitian Pembinaan dan Pengembangan Research Group tahun 2021. Tim peneliti mengucapkan terima kasih kepada semua pihak yang telah membantu, khususnya kepada para mahasiswa yang secara aktif telah terlibat, sehingga penelitian ini terlaksana dengan baik.

\section{Referensi}

Budhi, W. S., \& Kartasasmita, B. G. (2015). Berpikir matematis: Matematika untuk semua. Erlangga.

De Lange, J. (2006). Mathematical literacy for living from OECD-PISA perspective. Tsukuba Journal of Educational Study in Mathematics, 25, 13-35.

Jupri, A. (2019). Geometri dengan pembuktian dan pemecahan masalah. Jakarta: Bumi Aksara.

Jupri, A. (2020). Beberapa metode pembuktian teorema Viviani oleh mahasiswa calon guru matematika. Jurnal Pendidikan Matematika (Kudus), 3(2), 99-108. http://dx.doi.org/10.21043/jmtk.v3i2.718 8

Jupri, A. (2017). From geometry to algebra and vice versa: Realistic mathematics education principles for analyzing geometry tasks. 1830. https://doi.org/10.1063/1.4980938

Jupri, A., Fatimah, S., \& Usdiyana, D. (2020). Dampak perkuliahan geometri pada penalaran deduktif mahasiswa: Kasus pembelajaran teorema Ceva. AKSIOMA: Jurnal Matematika Dan Pendidikan
Matematika, 11(1), 93-104. https://doi.org/10.26877/aks.v11i1.6011

Jupri, A., Gozali, S. M., \& Usdiyana, D. (2020). An analysis of a geometry learning process: The case of proving area formulas. Prima: Jurnal Pendidikan Matematika, 4(2), 154-163. http://dx.doi.org/10.31000/prima.v4i2.26 19

Jupri, A., \& Rosjanuardi, R. (2020). An investigation of master student understanding on mathematical literacy problems. Jurnal Gantang, 5(1), 1-7. https://doi.org/10.31629/jg.v5i1.1828

Jupri, A., \& Syaodih, E. (2016). Between formal and informal thinking: The use of algebra for solving geometry problems from the perspective of Van Hiele theory. Jurnal Pengajaran MIPA, 21(2), 108-113.

Kawasaki, K. I. (2005). Proof without words: Viviani's theorem. Mathematics Magazine, $\quad 78(3), 213$. https://doi.org/10.1080/0025570X.2005. 11953328

Kemdikbud. (2013). Kurikulum 2013. Kompetensi dasar: Sekolah menengah pertama (SMP)/Madrasah Tsanawiyah $(M T s)$. Jakarta: Kementerian Pendidikan dan Kebudayaan.

Kemdikbud. (2017). Implementasi pengembangan kecakapan abad 21 dalam rencana pelaksanaan pembelajaran $(R P P)$ Jakarta: Kementerian Pendidikan dan Kebudayaan.

Koichu, B., \& Leron, B. (2015). Proving as problem solving: The role of cognitive decoupling. The Journal of Mathematical Behavior, $\quad 40, \quad 233-244$. https://doi.org/10.1016/j.jmathb.2015.10. 005

Levav-Waynberg, A., \& Leikin, R. (2012). The role of multiple solution tasks in developing knowledge and creativity in geometry. The Journal of Mathematical Behavior, 31(1), 73-90. 
https://doi.org/10.1016/j.jmathb.2011.11. 001

Masfingatin, T., Murtafiah, W., \& Krisdiana, I. (2018). Kemampuan mahasiswa calon guru matematika dalam pemecahan masalah pembuktian teorema geometri. Jurnal Mercumatika: Jurnal Penelitian Matematika Dan Pendidikan Matematika, 2(2), 41-50. https://doi.org/10.26486/jm.v2i2.272

Palatnik, A., \& Dreyfus, T. (2019). Students' reasons for introducing auxiliary lines in proving situations. The Journal of Mathematical Behavior, 55, 100679. https://doi.org/10.1016/j.jmathb.2018.10. 004

Polya, G. (1973). How to solve it: A new aspect of mathematical method (second edition). Princeton University Press. https://doi.org/10.2307/j.ctvc773pk

Posamentier, A. S., \& Stepelman, J. (1990). Teaching secondary school mathematics: Techniques and enrichment. New York: Merrill. https://doi.org/10.1142/11583

Samelson, H. (2003). Proof without words: Viviani's theorem with vectors. Mathematics Magazine, 76(3), 225. https://doi.org/10.1080/0025570X.2003. 11953185

Samo, D. D. (2017). Kemampuan pemecahan masalah matematika mahasiswa tahun pertama dalam memecahkan masalah geometri konteks budaya. Jurnal Riset Pendidikan Matematika, 4(2), 141-152. https://doi.org/10.21831/jrpm.v4i2.1347 0

Sukmadinata, S. S. (2012). Metode penelitian pendidikan. Bandung: Universitas Pendidikan Indonesia \& Remaja Rosja Karya.

Weber, K. (2005). Problem-solving, proving, and learning: The relationship between problem-solving processes and learning opportunities in the activity of proof construction. The Journal of Mathematical Behavior, 24(3-4), 351360.

https://doi.org/10.1016/j.jmathb.2005.09. 005

Widana, I. W. (2017). Modul penyusunan soal higher order thinking skill (HOTS). Jakarta: Kementerian Pendidikan dan Kebudayaan.

Yuwono, M. R. (2016). Analisis kesulitan mahasiswa dalam menyelesaikan soal geometri berdasarkan taksonomi Bloom dan alternatif pemecahannya. Beta: Jurnal Tadris Matematika, 9(2), 111133. https://doi.org/10.20414/betajtm.v9i2.7 